\title{
Mine Closure and Reclamation - Some Practical Examples in Different Climatic Settings
}

\author{
S. Barrett Water Management Consultants Pty Ltd, Australia \\ G. Beale Water Management Consultants Inc., USA \\ J. Reidel Water Management Consultants Inc., USA
}

\section{INTRODUCTION}

A number of major open pit hard rock mines have undergone closure over the past few years. These closed operations provide a unique opportunity to compare actual geochemical conditions with those predicted, and to identify factors which had the greatest influence on the success of closure implementation. This paper presents an overview of the open pit closure programs for the Sleeper mine in Nevada USA; the Golden Cross mine in New Zealand; and the Kori Kollo mine in Bolivia. In each of these cases, the local climate had a significant influence on the closure measures selected. Sleeper was the first of the current generation of large open pit gold mines in the western United States. The mine was rapidly flooded and a productive $200 \mathrm{~m}$ deep lake has been created. Golden Cross includes an open pit and several phases of underground workings, dating from the early 1900s. Following closure, the pit is allowed to free drain to an adjacent river. Kori Kollo lies next to the Rio Desaguadero and was the largest open pit mine on the Andean altiplano. Upon closure, it was necessary to design a flooding program to induce stratification in the pit lake.

\section{CLOSURE CONSTRAINTS}

At sites where sulphide bearing minerals are exposed to oxidation in pit slopes, underground workings, heap leach facilities or in waste rock storage facilities, the management of Acid Mine Drainage (AMD) becomes a primary constraint on the closure approach. In these cases, the key to successful closure is isolation of potentially acid generating material and minimising down-gradient flows. Ongoing chemical reactions have less influence on the overall closure conditions if the degree of contact with the active flow system is reduced. The potential for successful installation of down-gradient passive treatment or attenuation systems is increased if outflows from the site can be minimised.

Methods which have been successfully applied to achieve physical isolation include:

- Evaporation and creation of a hydraulic sink in arid environments.

- Permanent diversion of up-gradient water.

- Creation of preferential flowpaths through workings.

- Application of backfill or covers.

The most suitable approach is strongly influenced by the physiographic conditions at the site. In general the following observations are made from experience in implementing closure plans at a large number of operations:

- Open pits in arid environments.

- AMD remains local to site.

- It is physically possible to create hydraulic sinks.

- Evapo-concentration is a key constraint for closure. 
- Open pits in temperate/humid environments.

- AMD may potentially be flushed out and transported.

- Wall rocks potentially require cover and isolation or submergence.

- Mixing, hydrochemical adsorption, hydrochemical precipitation may act to minimise changes in the down-gradient environment.

- Underground mines in elevated terrain.

- Difficult to permanently submerge workings.

- Often permanent discharges occur through adits and tunnels.

- Site is typically more difficult to isolate.

- Underground mines in lowland terrain.

- Workings can often be permanently submerged below the water table.

- Down-gradient groundwater chemistry is typically the primary concern.

○ Often present the most straightforward closure implementation.

\section{PHYSIOGRAPHIC SETTINGS}

Details of the physical and meteorological conditions prevailing at each of the closed operations presented in the following sections are summarised in Table 1. Golden Cross is situated in sub-tropical rainforest and is an example of a relatively high precipitation environment. Sleeper is located on the eastern margin of the Desert Valley and is representative of arid conditions. In the alti-plano environment at Kori Kollo, significant precipitation is received, but is exceeded by evaporation.

\section{Table $1 \quad$ Physiographic data}

\begin{tabular}{|l|l|l|l|}
\hline Parameter & Golden Cross & Kori Kollo & Sleeper \\
\hline Continent & Australasia & South America & North America \\
\hline Country & New Zealand & Bolivia & USA \\
\hline Latitude & $37 \mathrm{~S}$ & $16 \mathrm{~S}$ & $41 \mathrm{~N}$ \\
\hline Altitude (mASL) & 400 & 3715 & 1260 \\
\hline Pit depth (m) & 150 & 260 & 200 \\
\hline Average annual precipitation (mm) & 2900 & 450 & 150 \\
\hline Average annual evaporation $(\mathrm{mm})$ & 900 & 1800 & 1830 \\
\hline
\end{tabular}




\section{SLEEPER GOLD MINE}

\subsection{Site Conditions}

The Sleeper mine is located in the Basin and Range province of Nevada, in the western USA. The ore body was hosted in Tertiary intermediate volcanic rocks with high pyrite content. The volcanics were unconformably overlain by Pliocene to Quaternary basin-fill alluvial sediments. The western pit wall encountered $50 \mathrm{~m}$ of saturated alluvium.

Open pit mining at Sleeper commenced in 1985. Initially the mine operated as a series of open pits (Wood, Office, Sleeper, Sleeper Northeast) until mining resulted in the pits merging in 1989. Mining of the open pit was staged, so that 30 million $t$ of the waste rock removed from active sections of the pit was placed in mined out sections of the pit, and functioned to buttress unstable sections of the pit slopes. Open pit mining was completed in March 1996 and the final pit was around $1800 \mathrm{~m}$ long, $900 \mathrm{~m}$ wide and $200 \mathrm{~m}$ deep.

Prior to mining, the depth to groundwater in the alluvial sequence overlying the pit was 10 to $15 \mathrm{~m}$. Dewatering during the mining phase was focussed on intercepting groundwater flow in the alluvial sequence, and the maximum dewatering rate required to control inflows was $1300 \mathrm{l} / \mathrm{s}$.

\subsection{Closure Approach}

As a result of the close connection between the alluvial groundwater system and the Sleeper Pit, a pit lake was an essential component of the closure approach. Detailed water balance studies demonstrated that due to the low precipitation conditions at the site and the large surface area of the lake for evaporation, the pit lake would act permanently as a hydraulic sink, with local groundwater flow being towards the pit lake. The primary constraint for the closure program was therefore the hydrochemistry of the pit lake, during filling and in the long term.

Hydrochemical characterisation data for each rock type, including column testing results, were employed to characterise the typical chemistry for each component in the lake water balance at each stage of filling. Resulting chemistry of the lake was predicted using the hydrochemical modelling package PHREEQC (Jacques et al., 2003) coupled with thermodynamic constants supplied from the geochemical database MINTEQ. Results were compared for various scenarios, including the placement of additional backfill and cover within the pit, natural vs accelerated filling, and the use of active water treatment during the filling stage.

Based on the hydrochemical studies, the adopted closure approach (Figure 1) was:

- Minimise the influence of potentially acid generating backfill within the open pit by the placement of oxide covers prior to lake filling.

- Accelerate filling of the pit lake by operating alluvial dewatering wells at around $1000 \mathrm{l} / \mathrm{s}$ and discharging to the pit. This served to:

- Minimise the exposure and oxidation period for the pit slopes and backfill material.

- Improve the quality of the pit lake during the filling phase.

- Increase the mixing of the lake water during filling.

- Provide an opportunity for active treatment of the lake waters.

- Apply lime dosing of the lake waters during filling. $12000 \mathrm{t}$ of lime was introduced to the lake via flow from the alluvial wells and a lime slaker operated from 1996 to 1998. This acted to neutralise acidity and precipitate metal hydroxides being liberated from the pit slopes and backfill during the filling process.

- Introduce nutrients during filling. Around $800 \mathrm{t}$ of manure was added to the lake to stimulate growth of algae and accelerate the establishment of aquatic biota. 
- Re-grade the upper alluvial slopes above the permanent pit lake, with alluvial material being pushed onto the lower pit slopes. Benefits to the pit lake were:

- Providing a more stable landform for the establishment of vegetation above the permanent lake.

- Liberating additional alkalinity within the pit lake, resulting from carbonate rich sediment horizons.

- Introducing additional dissolved and solid phase iron to the pit lake to maximise precipitation and adsorption of dissolved metals.

- Forming a blanket over the potentially acid generating material in the lower pit slopes.

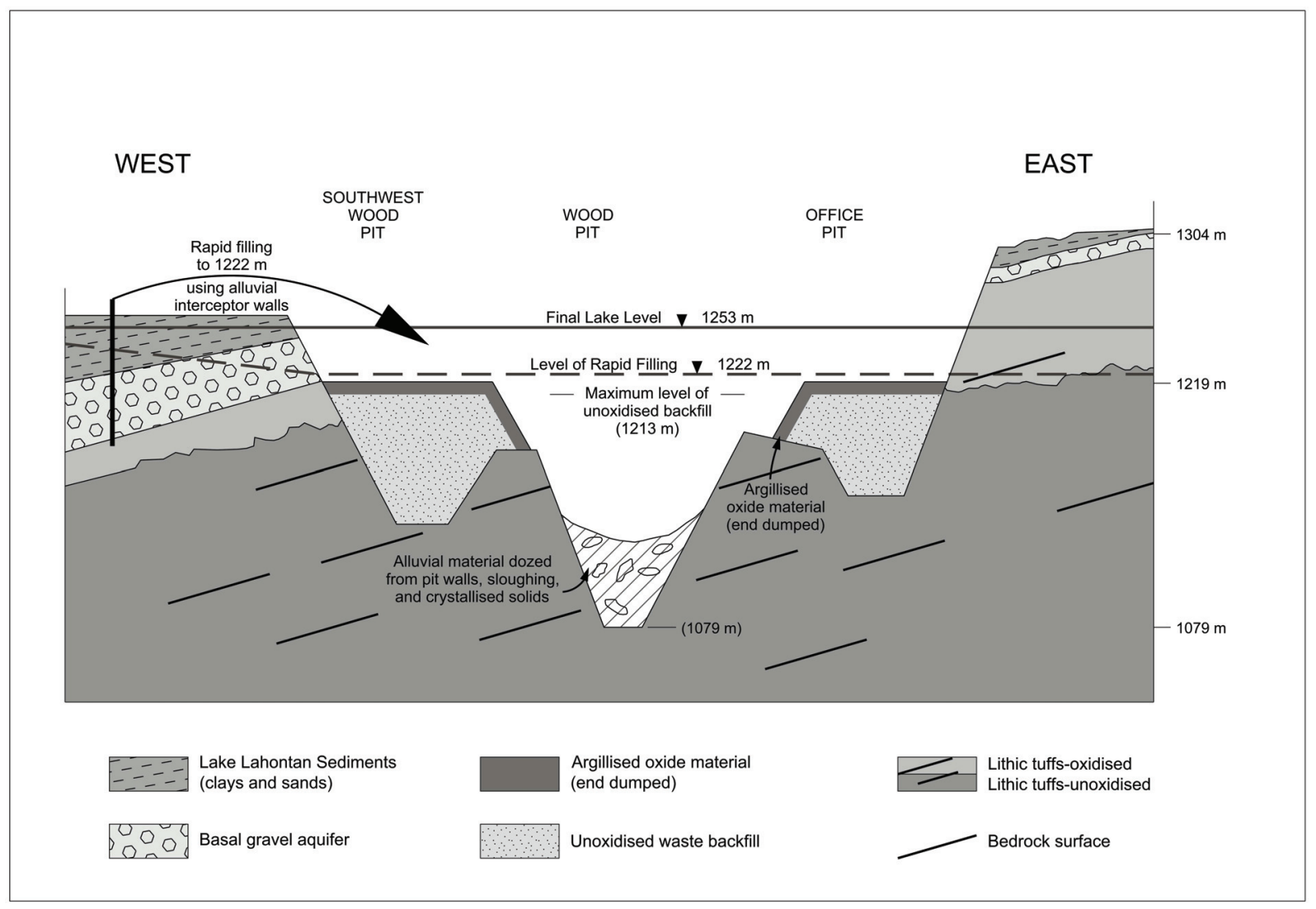

Figure 1 Schematic illustration of pit filling at the Sleeper Mine, Nevada, USA

\subsection{Closure Results}

The hydrochemical evolution of the Sleeper pit lake has been closely monitored during the filling stage (1996 to 1998) and in the period since the stable lake elevation was attained (1998 to 2006). During the initial filling stages, a significant amount of acidity was mobilised from the walls and backfill being flooded, resulting in lake water with $\mathrm{pH} 1.9$, and containing $32 \mathrm{mg} / \mathrm{l}$ arsenic, $9 \mathrm{mg} / \mathrm{l}$ copper, $28 \mathrm{mg} / 1$ manganese, $40 \mathrm{mg} / \mathrm{l}$ zinc and $6400 \mathrm{mg} / \mathrm{l}$ sulphate, as detailed in Table 2. At the end of the filling stage, the addition of alluvial groundwater, and active treatment of the lake water by lime and nutrient addition resulted in a lake water with $\mathrm{pH} 7.6$, and containing $0.002 \mathrm{mg} / 1$ arsenic, $0.007 \mathrm{mg} / 1$ copper, $0.098 \mathrm{mg} / 1$ manganese, $0.015 \mathrm{mg} / 1$ zinc and $1300 \mathrm{mg} / 1$ sulphate. 
Table 2 Sleeper pit lake hydrochemical data

\begin{tabular}{|l|c|c|}
\hline Parameter & Initial lake chemistry & $\begin{array}{l}\text { Five years after end } \\
\text { of filling (2003) }\end{array}$ \\
\hline Acidity & 4000 & 0 \\
\hline Alkalinity (total) & 0 & 62.9 \\
\hline PH & 1.9 & 7.6 \\
\hline Antimony & 0.12 & $<0.003$ \\
\hline Arsenic & 31.8 & 0.002 \\
\hline Cadmium & 0.12 & $<0.002$ \\
\hline Chloride & 178 & 280 \\
\hline Copper & 9.01 & 0.007 \\
\hline Iron & 1348 & $<0.05$ \\
\hline Magnesium & 253 & 52 \\
\hline Manganese & 27.7 & 0.098 \\
\hline Nickel & 16.1 & 0.06 \\
\hline Nitrate & 0.53 & 0.3 \\
\hline Potassium & 32 & 24 \\
\hline Selenium & 0.02 & 0.006 \\
\hline Sodium & 241 & 330 \\
\hline Sulphate & 6366 & 1330 \\
\hline Thallium & 1.37 & 0.002 \\
\hline Total Dissolved Solids & 9000 & 2480 \\
\hline Zinc & 39.5 & 0.015 \\
\hline
\end{tabular}

Note: All units mg/l except $\mathrm{pH}$ (specific units)

Regular vertical profiling of the lake since filling has confirmed that circulation is restricted to the upper $30 \mathrm{~m}$ of lake waters, with a significant thermocline present at $30 \mathrm{~m}$ depth in the summer months as illustrated in Figure 2. The lake fully turns over and mixes during the winter months. 


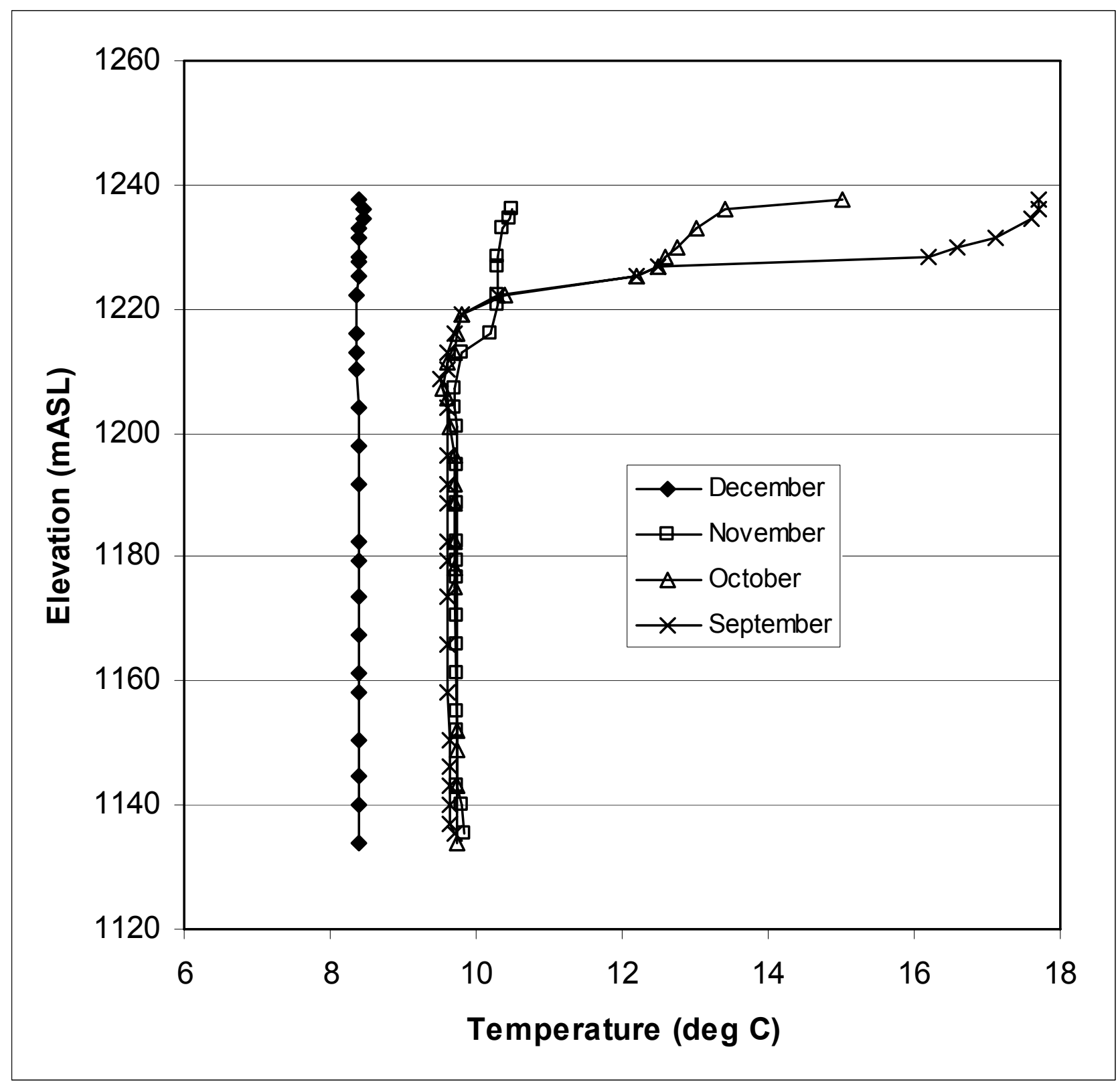

Figure 2 Vertical temperature profiles for Sleeper pit lake immediately following rapid filling

\section{GOLDEN CROSS MINE}

\subsection{Site Conditions}

The Golden Cross mine is located at the base of the Coromandel Peninsular in the North Island of New Zealand. The site is on the margin of a conservation area and within the headwaters of the Waitekauri River. Underground mining was undertaken from 1892 to 1917, with modern underground and open workings constructed in 1988. Closure investigations for the modern workings were initiated in 1997 and included extensive stakeholder and community consultation. The site is now fully rehabilitated.

The gold and silver ore body at Golden Cross was hosted in volcaniclastic andesite flows, which were defined to be highly acid generating. Runoff from the low grade stockpile was observed to have $\mathrm{pH} 2.8$, and to contain $7000 \mathrm{mg} / \mathrm{l}$ sulphate and $70 \mathrm{mg} / \mathrm{l}$ manganese. The ore body was overlain by intensely argillic 
altered breccia which formed a hydraulic barrier to vertical groundwater movement and by intensely leached andesite flows which had a soil-like texture as a result of alteration.

The Golden Cross mine comprised a series of veins and workings extending up a prominent ridge, from south to north as follows:

- The Empire South workings at around 270 mASL (with several levels of historical workings).

- The Golden Cross workings at around 300 mASL (historical workings).

- The Empire underground workings and open pit at around $400 \mathrm{mASL}$ (the modern workings).

During mining, the open pit was never actively dewatered, and surface water runoff pooling after significant precipitation events was observed to seep through the base of the pit to the underground workings, resulting in increased pumping demand from the Empire workings. Rates of recharge to the underground system were much greater than observed prior to mining, due to the open pit penetrating the argillic altered material which previously acted as a barrier to infiltration.

The Golden Cross vein and the Empire vein were found to be hydraulically isolated by the presence of the West Mine Fault. The Golden Cross vein remained saturated during initial mining and discharge was noted to continue from the Kiln adit while pumping from the Empire workings. However, after an exploration drive was extended from the Empire vein, through the West Mine Fault, and into the Golden Cross vein, hydraulic connection was established and the Golden Cross vein was observed to drain down. A schematic illustration of the groundwater flow system during mining is presented in Figure 3.

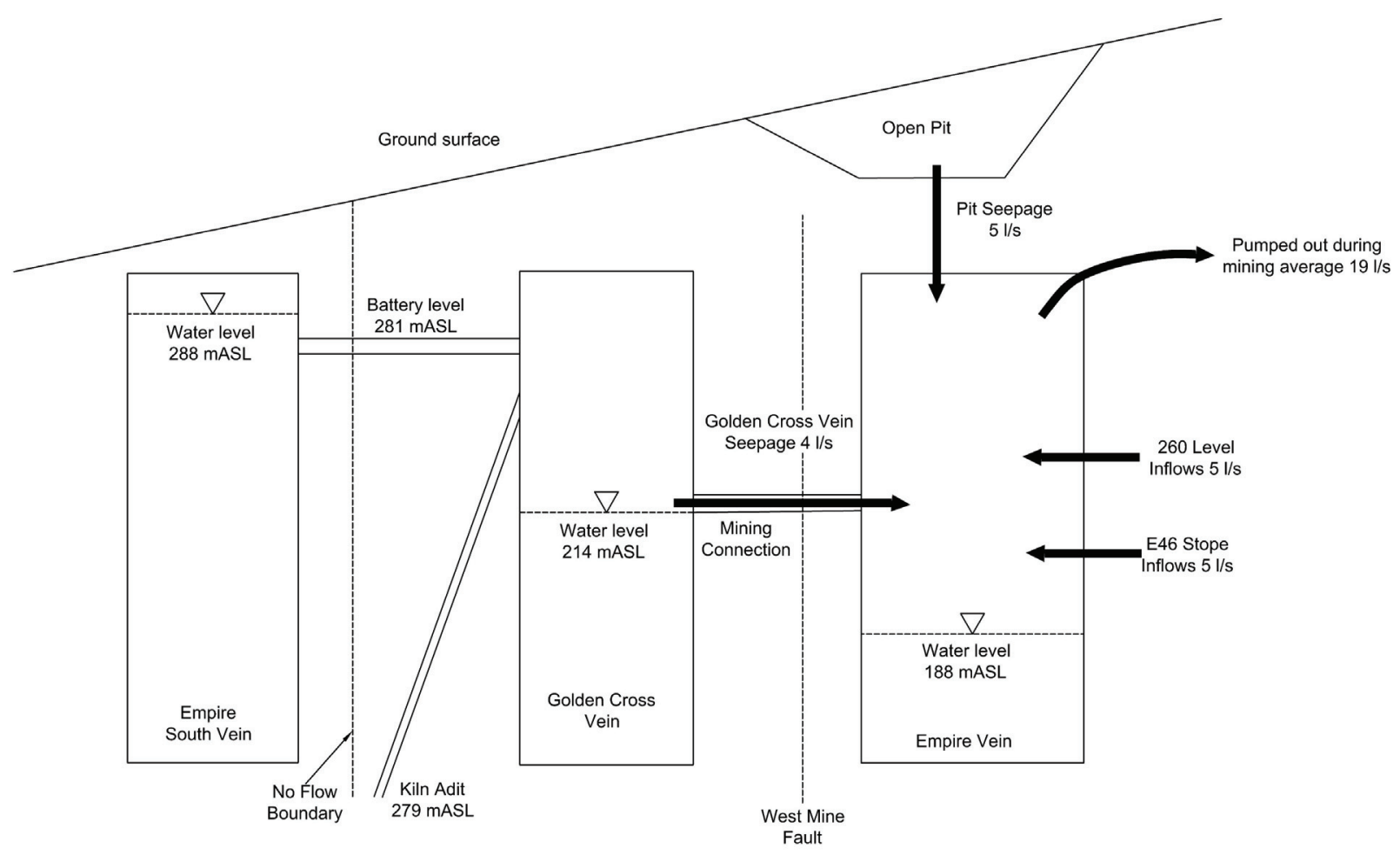

Figure 3 Schematic flows during mining at Golden Cross 


\subsection{Closure Approach}

Geotechnical investigations identified that it would not be possible to reinstate the hydraulic barrier between the Golden Cross and Empire workings by installing a plug within the exploration drive at $214 \mathrm{mASL}$. As a result, groundwater would flow from the Empire workings into the Golden Cross workings, and would discharge through the Kiln Adit which daylights at the Waitekauri River below the mine area (Figure 2). Hydrochemical modelling confirmed that discharge from the underground workings would require treatment for an extended period. The closure approach for the underground workings was therefore focussed on minimising inflow to the workings, and the resulting demand on a treatment system.

Hydrochemical modelling (calibrated to detailed wall runoff monitoring in the final year of open pit mining) indicated that if allowed to form, a lake in the Golden Cross open pit would have $\mathrm{pH}$ around 3 and a sulphate concentration around $300 \mathrm{mg} / \mathrm{l}$. Hydrogeological modelling confirmed that as a result of the high precipitation conditions, the pit lake would significantly increase flow through the underground workings, and a spillway would be required to allow discharge to the Waitekauri River.

The closure approach selected for the open pit and underground workings at Golden Cross comprised:

- Install a clay seal across the base and walls of the open pit. This incorporated a rigorous testing program to ensure that the main source of recharge to the underground workings was removed.

- Partially backfill the open pit using locally stockpiled waste rock. The backfill surface was given a dished geometry, sloping up from $320 \mathrm{mASL}$ at the new pit floor, to $390 \mathrm{mASL}$ on the pit highwall. This backfill geometry resulted in cover being placed over $90 \%$ of the pit wall rocks mapped as being acid generating.

- Excavate a notch cut in the pit wall at $320 \mathrm{mASL}$ to allow the pit surface to discharge to the Waitekauri River without pooling.

- Establish wetland vegetation at the base of the pit backfill surface.

- Route up-gradient runoff channels into the pit and through the notch cut. This included the overflow from the tailings facility which was closed as a permanent lake.

- Install limestone lining in clean water up-gradient channels. Site trials using locally available limestone confirmed that clean water flowing through limestone drains, when mixed with acid runoff, resulted in reductions of between $5 \%$ and $50 \%$ in concentrations of copper, iron, manganese, nickel and zinc.

- Rapidly flood the underground workings by diverting surface water drainage into a vent raise.

- Install discharge containment at the Kiln Adit and flow alarms at all other historical adits.

- Route underground discharge to the water treatment plant, until an anaerobic upflow wetland is established to treat the flows.

\subsection{Closure Results}

During implementation of the closure plan, water pooling in the sealed open pit was sampled, as this would be representative of a pit lake if allowed to form. During initial flooding of the underground workings, prior to removing access, the mixed underground flow was sampled. Table 3 summarises the results of the open pit and underground sampling, and compares the results against model predictions. In general the results demonstrate good agreement with model predictions and indicate that in most cases the modelling approach was slightly conservative. 
Table $3 \quad$ Actual vs model chemistry

\begin{tabular}{|l|l|l|l|l|l|l|l|}
\hline Sample & $\mathbf{p H}$ & $\begin{array}{l}\mathbf{S O}_{4} \\
(\mathbf{m g} / \mathbf{l})\end{array}$ & $\begin{array}{l}\mathbf{C a} \\
(\mathbf{m g} / \mathbf{l})\end{array}$ & $\begin{array}{l}\mathbf{F e} \\
(\mathbf{m g} / \mathbf{l})\end{array}$ & $\begin{array}{l}\mathbf{M n} \\
(\mathbf{m g} / \mathbf{l})\end{array}$ & $\begin{array}{l}\mathbf{C u} \\
(\mathbf{m g} / \mathbf{l})\end{array}$ & $\begin{array}{l}\mathbf{Z n} \\
(\mathbf{m g} / \mathbf{l})\end{array}$ \\
\hline Open pit lake actual & 3.2 & 656 & 161 & 2.01 & 7.99 & 0.03 & 0.19 \\
\hline Open pit lake model & $3-4$ & $200-300$ & $40-100$ & $7-10$ & $1-3$ & $0.02-0.05$ & $0.1-0.3$ \\
\hline Underground flooding actual & 3.3 & 826 & 201 & 15 & 17.5 & 0.07 & 0.6 \\
\hline Underground flooding model & $2-3.5$ & $1500-2200$ & $300-500$ & $50-120$ & $20-40$ & $0.01-0.03$ & $1-2$ \\
\hline
\end{tabular}

Closure and reclamation works at Golden Cross are now complete, and the site is used as grazing land and includes a public guided heritage walk comparing the mining landform with the reclaimed landform. The open pit drainage system is working successfully and the notch cut discharges directly to the Waitekauri River.

Inflows and hydrochemistry in the underground workings responded as predicted, and confirmed the inferred elevation of connection between each of the vein systems. The water level was allowed to rise $6 \mathrm{~m}$ above the Kiln Adit portal, without discharge being observed. It is evident that the Kiln Adit has collapsed during mining and no longer acts as a discharge structure. A vertical well was drilled into the workings and is currently employed to control the flooding elevation and prevent discharge from any unmapped drives or adits. Flow from the well is treated through a combination of a passive treatment upflow wetland and an active treatment facility. Investigations are underway to determine the optimum discharge control and treatment system for long term management of the underground workings.

\section{$6 \quad$ KORI KOLLO MINE}

\subsection{Site Conditions}

The Kori Kollo mine is located in the mining district of La Joya in Bolivia. The gold deposit was mined from a single open pit in the period 1991 to 2002. The mine is situated at $3715 \mathrm{mASL}$ on the Bolivian altiplano, and the pit walls are within $100 \mathrm{~m}$ of the Rio Desaguadero, which drains Lake Titicaca. Total pit depth at the end of mining was $260 \mathrm{~m}$. The ore body was hosted in dacite, with a high sulphur content.

The local groundwater system is typical of evaporate environments and demonstrates increasing salinity with depth, up to $300000 \mathrm{mg} / \mathrm{l}$ TDS at a depth of $300 \mathrm{~m}$, with naturally elevated concentrations of arsenic and manganese. During mining operations, the total flow from the dewatering system (alluvial and bedrock interceptor wells) was around $900 \mathrm{l} / \mathrm{s}$, and flow was recharged to the alluvial system using evaporation/infiltration basins, located $3 \mathrm{~km}$ from the open pit.

On cessation of dewatering operations, groundwater inflow resulted in the formation of an initial lake at the base of the pit with volume $1 \times 10^{6} \mathrm{~m}^{3}$, and a TDS concentration of around $120000 \mathrm{mg} / \mathrm{l}$. 


\subsection{Closure Approach}

The key issue for closure was the elevated groundwater pore pressures occurring within the pit walls. Allowing the lake to full naturally would have created significant slope failures which would have had a negative effect on the final lake chemistry. The closure approach therefore focused on rapid filling and recovery of the lake to equalize the high pore pressures in the pit slopes. In addition the rapid filling process minimised the contribution of deep groundwater during pit filling and enhanced stratification within the lake. The following program was implemented:

- In 2003, the pit was rapidly filled over a 4 month period using flow diverted from the Rio Desaguadero at rates of 10000 to $15000 \mathrm{l} / \mathrm{s}$.

- Lime amendment of the lake water was carried out during and following the rapid filling phase.

- Manure and fertilizer were added to the lake during filling in order to promote algal development and stimulate the aquatic habitat.

- The upper slopes were re-graded and vegetated with native aquatic plants.

Since completion of the rapid filling program in mid-2003, river water has been introduced on a seasonal basis. The final closure configuration for the lake will incorporate continual circulation of water from the Rio Desaguadero through the upper portion of the lake, providing a source of low TDS water, and maintaining the lake elevation at a position where on-going high TDS groundwater inflow is minimised.

\subsection{Closure Results}

Monitoring of the Kori Kollo pit lake indicates that:

- The upper $100 \mathrm{~m}$ of the lake has a pH in the range 6 to 8 and TDS concentration around 1,700 mg/l. this is almost identical to the adjacent Rio Desaguadero. Below $100 \mathrm{~m}$ depth, a chemocline is present, with TDS concentrations increasing from $1800 \mathrm{mg} / 1$ to $60000 \mathrm{mg} / \mathrm{l}$.

- In summer, thermal gradients result in seasonal stratification of the upper $30 \mathrm{~m}$ of the lake. In winter, mixing of the upper $100 \mathrm{~m}$ of the lake occurs, due to the reduced thermal gradients, and the occurrence of significant wind driven currents.

- Increasing TDS of the upper lake due to mixing in winter is offset by shallow inflows during summer.

- Fish entering the lake with river water are thriving in the shallow aquatic environment.

\section{$7 \quad$ CONCLUSIONS}

Closure works which have been completed at the Sleeper, Golden Cross and Kori Kollo mines illustrate the influence of climatic conditions on the optimum closure approach. Low precipitation at the Sleeper site allowed the creation of a pit lake which acted as a hydraulic sink, and required active treatment and accelerated flooding during the filling period to optimize the pit lake water quality. At Golden Cross, high precipitation conditions would have caused a pit lake to discharge, and a partial backfill approach was adopted for the open pit. While the pit lake developed at Kori Kollo would potentially act as a hydraulic sink, the input of river flows has been employed to minimize the amount of high TDS groundwater entering the lake.

\section{REFERENCES}

Jacques, D., Šimünek, J., Mallants D. and van Genuchten, M.T. (2003) The HYDRUS-PHREEQC multicomponent transport model for variably-saturated porous media: code verification and application. In: E. Poeter, Z. Zheng, M. Hill, J. Doherty (eds), MODFLOW and more: understanding through modeling: conference proceedings, International Ground Water Modeling Center, Colorado School of Mines, September 16-19, 2003, Colorado School of Mines, Golden, pp. 23-27. 